Volume 56

Issue 3 Exonerating the Innocent: Pretrial

Innocence Procedures

Article 4

January 2012

\title{
Adversarial Inquisitions: Rethinking the Search for the Truth
}

Keith A. Findley

University of Wisconsin Law School

Follow this and additional works at: https://digitalcommons.nyls.edu/nyls_law_review

Part of the Law Commons

\section{Recommended Citation}

Keith A. Findley, Adversarial Inquisitions: Rethinking the Search for the Truth, 56 N.Y.L. SCH. L. REV. 927 (2011-2012).

This Article is brought to you for free and open access by DigitalCommons@NYLS. It has been accepted for inclusion in NYLS Law Review by an authorized editor of DigitalCommons@NYLS. 
KEITH A. FINDLEY

\section{Adversarial Inquisitions: Rethinking the Search for the Truth}




\section{ADVERSARIAL INQUISITIONS: RETHINKING THE SEARCH FOR THE TRUTH}

If one were asked to start from scratch and devise a system best suited to ascertaining the truth in criminal cases, and to ensuring that, to the extent any unavoidable errors in fact-finding occur, they do not fall on the shoulders of innocent suspects, what would that system look like? It is inconceivable that one would create a system bearing much resemblance to the criminal justice process we now have in the United States.

The current American system is marked by an adversary process so compromised by imbalance between the parties-in terms of resources and access to evidencethat true adversary testing is virtually impossible. It is a system in which competing litigants, unequal as they are, control everything from the investigation to presentation of the evidence, and in which their motivation in that process is to win, more than to discover the truth. So motivated, litigants coach witnesses, suppress facts, employ tricks and surprises, distort the truth, and manipulate fact finders. ${ }^{1}$ The result is a system that we now know, through the growing record of wrongful convictions, is prone to an unacceptably high rate of false convictions, as well as failures to convict the guilty. ${ }^{2}$

Driven by the numerous wrongful convictions discovered in the past two decades, some observers have begun to think about ways to redesign the search for the truth. In particular, some scholars have suggested special "innocence procedures"-new judicial procedures that can be invoked by accused individuals who plead "innocent" as opposed to "not guilty" and that require both sides in the process to give up some of their adversarial advantages in order to permit more reliable access to the truth. ${ }^{3}$

Those proposals offer an important first step in thinking about ways to make the fact-finding processes more reliable. They revisit the long-standing debates about the merits of the adversarial system as it is practiced in common law countries, such as

1. Jerome Frank, Courts on Trial: Myth and Reality in American Justice (1949); Marvin E. Frankel, Partisan Justice (1978); William T. Pizzi, Trials Without Truth: Why Our System of Criminal Trials Has Become an Expensive Failure and What We Need to Do to Rebuild Iт (1999); John H. Langbein, The German Advantage in Givil Procedure, 52 U. CHI. L. Rev. 823, 833-34 (1985); Dan Simon et al., Adversarial and Non-Adversarial Investigations: An Experiment (May 15, 2009) (unpublished manuscript), available at http://papers.ssrn.com/sol3/papers.cfm?abstract_ id $=1401723$.

2. As of this writing, at least 278 individuals convicted of serious crimes-almost all rapes and murdershave been exonerated by postconviction DNA testing alone. Know the Cases: Innocence Project Case Profiles, Innocence Project, www.innocenceproject.org/know/ (last visited Nov. 10, 2011). Hundreds more have been exonerated by other types of evidence as well. See, e.g., Samuel R. Gross et al., Exonerations in the United States 1989 Through 2003, 95 J. Crim. L. \& Criminology 523 (2005).

3. See Tim Bakken, Truth and Innocence Procedures to Free Innocent Persons: Beyond the Adversarial System, 41 U. Мich. J.L. Reform 547 (2008); D. Michael Risinger, Unsafe Verdicts: The Need for Reformed Standards for the Trial and Review of Factual Innocence Claims, 41 Hous. L. Rev. 1281, 1312 (2004); Lewis M. Steel, Op-Ed., Building a Justice System, News \& Observer (Raleigh), Jan. 10, 2003, at A17. Michael Risinger, now joined by Lesley Risinger in this symposium issue, expands upon his initial proposal and now helpfully addresses pretrial investigation procedures as well as adjudication processes. D. Michael Risinger \& Lesley C. Risinger, Innocence Is Different: Taking Innocence into Account in Reforming Criminal Procedure, 56 N.Y.L. Sch. L. Rev. 869 (2011-12). 
the United States, ${ }^{4}$ versus the Continental inquisitorial system. ${ }^{5}$ To a large extent, they suggest transposing some features of the inquisitorial system and its focus on truth-finding onto the American adversarial system. I fear, however, that in doing so these proposals fail to fully account for the full range of cultural and psychological factors-from the adversarial culture that engenders a prosecutorial "conviction mentality" 6 to innate cognitive distortions such as confirmation bias ${ }^{7}$ - that can obstruct the search for the truth in the American system.

This article builds upon those initial proposals for "innocence procedures." In Part II, the article considers the features of the current American adversarial system that impede the search for the truth. Part III briefly examines the emerging record of false convictions the American system has produced. Part IV analyzes and critiques some of the early proposals for new "innocence procedures" that have been offered as mechanisms for better finding the truth in cases where the defendant seriously claims innocence. Focusing solely on the investigative and trial phases of the process, ${ }^{8}$ Part $\mathrm{V}$ presents an alternative model that draws on the most effective aspects of both the adversarial and inquisitorial systems-a combination that has the potential for accommodating both the inquisitorial system's interest in objective discovery of the truth and the American system's deeply entrenched culture of adversarial advocacy.

This article envisions a new optional system, centered around something that might be called an Office of Public Advocacy, in which lawyers alternate between acting as prosecutors and as defense attorneys, and in which both the adversarial prosecutor and defense attorney share in guiding the inquisitorial process of investigating the case and developing the evidence. It suggests, in the end, reinforcing the power of adversarial advocacy by joining the competing forces in the adversary process in a shared enterprise for discovering the truth.

4. Adversary systems are marked by party control of the investigation and presentation of evidence. Adversaries, each motivated by a desire to win (rather than a purely objective quest for the truth), search for evidence, present their versions of the evidence, and challenge the evidence presented by the adverse party while the judge and jury, as neutral decisionmakers, play a passive role in receiving the evidence and then evaluating it to determine the truth. Proponents of the adversary system contend that adversary testing is essential to a full exploration of the facts necessary to ensure reliable fact-finding. See Lon L. Fuller, The Forms and Limits of Adjudication, 92 Harv. L. Rev. 353, 383-84 (1978); Gerald Walpin, America's Adversarial and Jury Systems: More Likely to Do Justice, 26 Harv. J.L. \& Pub. Pol’y 175 (2003).

5. In an inquisitorial system, a neutral magistrate, rather than the parties themselves, undertakes the task of managing the investigation and developing and presenting the evidence, motivated solely by an interest in finding the truth. The parties play a less direct role in the process, although often the prosecutor is cast in the role of a neutral inquisitor, whose task is defined just as much by the duty to acquit the innocent as convict the guilty. See Mirjan Damaška, Presentation of Evidence and Factfinding Precision, 123 U. PA. L. Rev. 1083, 1088-90 (1975). Proponents of inquisitorial systems argue that, by focusing directly on the truth, rather than on the parties' interests in winning, the process more reliably accesses the truth. See Robert P. Mosteller, Failures of the American Adversarial System to Protect the Innocent and Conceptual Advantages in the Inquisitorial Design for Investigative Fairness, 36 N.C. J. INT'L L. \& Com. Reg. 319 (2011).

6. See infra notes $105-06$ and accompanying text.

7. See infra notes 95-96, 122-26, and 151-53 and accompanying text.

8. Appellate and post-conviction procedures are beyond the scope of this article. 


\section{ADVERSARIAL INQUISITIONS: RETHINKING THE SEARCH FOR THE TRUTH}

At the outset, I recognize that this thought experiment must be tentative, designed more to encourage debate than immediate overhaul. As Michael Risinger has cautioned, the law of unintended consequences urges deliberateness and care. ${ }^{9}$ Nonetheless, the thought experiment is one worth undertaking, given the pressing need to do better at sorting the innocent from the guilty.

\section{BARRIERS TO THE TRUTH IN THE AMERICAN ADVERSARIAL SYSTEM}

The current American system is simply not well designed to find the truth. While we purport to have created, and to have tremendous confidence in, an adversarial model of truth-adjudication, ${ }^{10}$ the adversary system in the United States, in reality, is not structured in a way that truly permits full adversarial testing of the evidence. The adversary system operates on the fundamental belief that the best way to ascertain the truth is to permit adversaries to do their best to prove their competing version of the facts. When two equal adversaries compete in this way, the theory goes, falsehoods are exposed and the truth emerges. Implicit in that idealized model is the assumption that the adversaries are roughly equal, for only when adversaries are evenly matched can there be much hope that adversary testing of the evidence will expose the bare truth.

Yet the adversaries in our system are anything but equal. And, as I have described in detail previously, the playing field is anything but balanced. ${ }^{11}$ Chronic underfunding of representation for indigent defendants has been widely noted, and is so pervasive and problematic that it often "effectively means that the prosecution lacks an effective opponent to challenge its allegations and evidence." ${ }^{12}$ Moreover, only one side- the State-has access to all of the crime scene evidence and all of the government's resources to collect the evidence. Typically, the accused has few resources to permit a serious independent investigation. Although the fact-development stage of the process usually determines the outcome of the case, only the State typically has much ability to look for and produce the key evidence in the case. Indeed, in a significant percentage of cases, the defense undertakes virtually no independent investigation. ${ }^{13}$

9. Risinger, supra note 3, at 1312.

10. See Walpin, supra note 4. But see Amalia D. Kessler, Our Inquisitorial Tradition: Equity Procedure, Due Process, and the Search for an Alternative to the Adversarial, 90 Connell L. Rev. 1181 (2005) (arguing that, as late as the nineteenth century, Anglo-American courts of equity employed a mode of procedure derived from the Roman-canon tradition that was significantly inquisitorial).

11. See Keith A. Findley, Innocents at Risk: Adversary Imbalance, Forensic Science, and the Search for Truth, 38 Seton Hall L. Rev. 893, 897-929 (2008).

12. Mosteller, supra note 5, at 323. Mosteller argues that underfunding of defense legal services is so severe that "it alters the basic character of American justice from its essential adversarial design." Id. at 326; see also Am. Bar Ass'n Standing Comm. On Legal Aid \& Indigent Defendants, Gideon's Broken Promise: America's Continuing Quest for Equal Justice 7 (2004) (observing that the funding and structure of defense services for the indigent leads to crushing caseloads that produce "widespread breaches of professional obligations").

13. See Michael McConville \& Chester L. Mirsky, Criminal Defense of the Poor in New York City, 15 N.Y.U. Rev. L. \& Soc. Change 581, 762 (1987) (finding that appointed defense attorneys in New York 
Beyond such disparities, the American system is not one designed to serve truthseeking in other respects. It is a system, for example, in which both sides can keep much if not most of their evidence secret before trial. Of course, the State operates under constitutional duties to disclose material exculpatory evidence, ${ }^{14}$ the defense often must disclose alibi defenses before trial, ${ }^{15}$ and both parties usually must disclose prior statements of their witnesses, although often not until they testify. ${ }^{16}$ But such disclosure obligations are exceptions, not the rule. Broad discovery is notoriously absent in criminal cases. ${ }^{17}$ The result is a tendency toward trial by ambush-both sides try to hold their cards until the last minute, hoping to gain an advantage by springing them on the other side. Such a process is hardly a prescription for accuracy. ${ }^{18}$

Similarly, the way we produce and present forensic science evidence — an increasingly essential element in criminal cases—is not designed to maximize truth finding. Almost all crime laboratories are situated within law enforcement agencies, leading to the risk that the laboratories will be captured by police and prosecutor interests in obtaining convictions rather than pursuing objective truth. ${ }^{19}$ Lab analysts ply their trade not in the objective and neutral settings of an academic or clinical scientific laboratory, but in the biasing and pressurized environs of a law-enforcement agency charged with

conducted an investigation in only twenty-seven percent of all homicide cases, twelve percent of other felonies, and less than eight percent of all misdemeanors); see also C. Ronald Huff, Wrongful Convictions in the United States, in Wrongful Convictions: International Perspectives on Miscarriages of Justice 59, 64-65 (C. Ronald Huff \& Martin Killias eds., 2008); Darryl K. Brown, The Decline of Defense Counsel and the Rise of Accuracy in Criminal Adjudication, 93 Calif. L. Rev. 1585, 1601-02 (2005); Andrew D. Leipold, How the Pretrial Process Contributes to Wrongful Convictions, 42 Aм. CRim. L. Rev. 1123, 1127 (2005).

14. Brady v. Maryland, 373 U.S. 83 (1963).

15. E.g., Fed. R. CRim. P. 12.1.

16. E.g., Jencks Act, 18 U.S.C. $\S 3500$ (2006); FED. R. CRim. P. 16, 26.2.

17. See Mary Prosser, Reforming Criminal Discovery: Why Old Objections Must Yield to New Realities, 2006 Wis. L. Rev. 541, 549, 582; George C. Thomas III, Two Windows into Innocence, 7 Oнio St. J. Crim. L. 575, 590 (2010); Mosteller, supra note 5, at 331.

18. See generally Gordon Van Kessel, Adversary Excesses in the American Criminal Trial, 67 Notre Dame L. Rev. 403 (1992).

19. This is not a suggestion that crime laboratory analysts are necessarily or even often subjectively biased. It is, rather, to suggest that analysts working in a law enforcement environment inevitably are susceptible to pressures and information that can produce unintentional biasing from "observer effects." See D. Michael Risinger et al., The Daubert/Kumho Implications of Observer Effects in Forensic Science: Hidden Problems of Expectation and Suggestion, 90 CaLIF. L. Rev. 1 (2002). Indeed, research confirms that when forensic science analysts, such as fingerprint analysts, are provided with non-scientific information about a suspect's guilt or innocence, that non-scientific evidence frequently skews the analysts' interpretations of the scientific evidence. Itiel E. Dror, David Charlton \& Ailsa E. Péron, Contextual Information Renders Experts Vulnerable to Making Erroneous Identifications, 156 Forensic Sci. Int'l 74 (2006); see also Kent Roach, Forensic Science and Miscarriages of Justice: Some Lessons from a Comparative Experience, 50 Jurimetrics 67, 81-82 (2009) (discussing recommendations of the National Academy of Sciences about the need to insulate crime laboratories from the dangers of confirmation bias (citing Coмm. on Identifying the Needs of the Forensic Sci. Comty. et al., Nat'l Research Council of the Nat'l Acads., Strengthening Forensic Science in the United States: A Path Forward (2009))). 


\section{ADVERSARIAL INQUISITIONS: RETHINKING THE SEARCH FOR THE TRUTH}

developing the evidence needed to convict a suspect. ${ }^{20}$ Moreover, these state or local police forensic science laboratories-the central repositories of forensic science experts and facilities - are available predominantly if not exclusively to law enforcement. ${ }^{21}$ And to the extent that the parties-prosecution and defense alike-seek experts outside the state laboratories, the experts are typically paid and selected because they will say what the party wants. Objective truth takes a back seat.

Non-expert witnesses are also subject to truth-subverting pressures. There is no requirement that witnesses for one side talk to the other side before trial, and they often refuse to do so. Instead, lawyers for both sides engage in private discussions with their witnesses to coach them to say things in the way most helpful to that side, with no requirement that a complete record be made of those conversations. ${ }^{22}$ Without equal access to the witnesses, adversarial testing of the witnesses' statements is compromised. ${ }^{23}$ Moreover, the mere rehearsal of testimony with counsel itself inevitably corrupts the search for the truth. Research shows that witnesses who rehearse their testimony-even lying witnesses-become more persuasive over time; observers become less accurate when judging prepared statements than when judging unprepared ones, and deceitful witnesses become more believable after successive interviews. ${ }^{24}$

After trial, the system continues to approach truth-finding only indirectly. Appeals focus almost entirely on procedural regularity, with little opportunity to directly assess substantive claims of innocence, or even to consider newly discovered evidence of innocence. ${ }^{25}$ It is axiomatic that assessment of the evidence-that is,

20. See, e.g., William C. Thompson, A Sociological Perspective on the Science of Forensic DNA Testing, 30 U.C. Davis L. Rev. 1113 (1997).

21. See Keith A. Findley \& Michael S. Scott, The Multiple Dimensions of Tunnel Vision in Criminal Cases, 2006 Wis. L. Rev. 291, 393-94.

22. Ethics rules permit lawyers to prepare witnesses and to talk with them extensively about their testimony before trial. Restatement (Third) of Law Governing Lawyers § 116 (2000); see Langbein, supra note 1, at 833-34 (describing how skillful coaching of witnesses undermines the witnesses' ability or desire to testify in a fully truthful manner).

23. Research shows that witness preparation has a significant effect on shaping the witness's testimony, often in ways that make the testimony less faithful to the truth. See Blair H. Sheppard \& Neil Vidmar, Adversary Pretrial Procedures and Testimonial Evidence: Effects of Lawyer's Role and Machiavellianism, 39 J. Personality \& Soc. Psychol. 320, 321-25 (1980) (finding that, after being interviewed by a simulated lawyer, witness testimony became skewed to favor that lawyer's interests); Gary L. Wells et al., The Tractability of Eyewitness Confidence and Its Implications for Triers of Fact, 66 J. Applied Psychol. 688, 693 (1981) (finding that forewarning a prosecution witness about an expected hostile cross-examination by the defense attorney resulted in a strengthening of the witness's confidence, especially in circumstances in which the witness's testimony was actually mistaken); see also Neil Vidmar \& Nancy MacDonald Laird, Adversary Social Roles: Their Effects on Witnesses' Communication of Evidence and the Assessments of Adjudicators, 44 J. Personality \& Soc. Psychol. 888, 893-95 (1983).

24. See Charles F. Bond, Jr. \& Bella M. DePaulo, Accuracy of Deception Judgments, 10 Personality \& Soc. Psychol. Rev. 214, 219 (2006); Pär Anders Granhag \& Leif A. Strömwall, Repeated Interrogations: Verbal and Non-Verbal Cues to Deception, 16 Applied Cognitive Psychol. 243, 254 (2002); Dan Simon, The Limited Diagnosticity of Criminal Trials, 64 Vand. L. Rev. 143, 180 (2011).

25. See Keith A. Findley, Innocence Protection in the Appellate Process, 93 Marq. L. Rev. 591, 601-08 (2009). 
determination of the truth revealed by the evidence-is reserved almost exclusively to the jury (or the trial judge in a bench trial). ${ }^{26}$ Appeals instead focus almost entirely on process questions-was the trial conducted in accordance with the rules? - rather than truth questions. Truth is simply not a central or often even significant concern on appeal.

The system also deliberately pursues a variety of values and objectives unrelated to and indeed sometimes inconsistent with truth-seeking. Various exclusionary rules, for example, sometimes limit access to the full truth based on values such as respect for "individual dignity, privacy, [and] freedom from unreasonable state regulation." ${ }^{27}$ Privacy rights protected by the Fourth Amendment, for example, can lead to the exclusion of undeniably relevant and reliable evidence. ${ }^{28}$ Beyond rights enforced by exclusionary rules, other constitutional values similarly conflict at times with truth seeking; "the Double Jeopardy Clause also protects [such] truth-impairing value[s] [as] relieving the accused of the 'embarrassment, expense, ... and anxiety and insecurity' of repeated trials." ${ }^{29}$ In such circumstances, however, unlike the other truth-compromising features of the system mentioned above, the truth in these instances is compromised knowingly, based on and justified by an explicit weighing of competing values. ${ }^{30}$

This list of truth-obstructing features of the current system is not exhaustive. But it is enough for purposes of this article to demonstrate that the current system has plenty of room for improvement, if truth is truly the objective.

26. Only limited exceptions to this axiom exist, such as the limited opportunity for review under the Due Process Clause for sufficiency of the evidence. But that review is extremely narrow and deferential. Under Jackson v. Virginia, 443 U.S. 307, 319 (1979), appellate courts may reverse a conviction because of insufficient evidence only if, taking the evidence in the light most favorable to the prosecution, there is insufficient evidence upon which a rational jury could find guilt. "Although the Supreme Court in Jackson cautioned against equating this rule with a 'no-evidence' standard, most courts have applied the standard so deferentially that in practice they uphold convictions unless there is essentially no evidence supporting an element of the crime." Findley, supra note 25, at 602 (footnote omitted).

27. Franklin Strier, Making Jury Trials More Truthful, 30 U.C. DAvis L. Rev. 95, 107 (1996).

28. See Tom Stacy, The Search for the Truth in Constitutional Criminal Procedure, 91 Colum. L. Rev. 1369, 1374-76 (1991). Some commentators suggest that the privilege against self-incrimination similarly compromises the search for the truth, in the interest of serving other values. As argued below, however, I contend that the privilege does not impede the search for the truth, but may in fact facilitate that search. See infra Part III.

29. Stacy, supra note 28, at 1380-81 (quoting Green v. United States, 355 U.S. 184, 187 (1957)). Unlike the Fourth Amendment, however, the Double Jeopardy Clause also, in part, serves truth-enhancing functions: "By barring repeated attempts to convict a person for the same offense, the [Double Jeopardy] Clause diminishes the possibility that an innocent person will be found guilty." Id. at 1380 (citing United States v. Martin Linen Supply Co., 430 U.S. 564, 569 (1977)).

30. E.g., Herring v. United States, 555 U.S. 135, 141 (2009) (observing that the exclusionary rule is employed for its deterrent value in checking police misconduct and that it can exact a "costly toll upon truth-seeking and law enforcement objectives" (quoting Pa. Bd. of Prob. \& Parole v. Scott, 524 U.S. 357, 364-65 (1988))). 


\section{ADVERSARIAL INQUISITIONS: RETHINKING THE SEARCH FOR THE TRUTH}

\section{THE RECORD OF FAILURE IN THE AMERICAN ADVERSARIAL SYSTEM}

The failure of the American adversarial system to ensure reliable outcomes and to protect the innocent is by now beyond dispute. The evidence of wrongful convictions that has emerged in the past two decades is clear and disturbing. To date, more than 270 individuals convicted of serious felonies (almost all rapes and murders) have been exonerated by new DNA evidence alone, usually after many years of wrongful imprisonment, and after the trial and appellate safeguards against error all failed. ${ }^{31}$

Those exonerations undoubtedly represent, as numerous observers have put it, the tip of what is surely a very large iceberg. ${ }^{32}$ Those exonerations include only convictions proved false by DNA evidence. Yet DNA evidence exists in only a small percentage of cases. And even where biological evidence capable of producing a DNA profile once existed, DNA exoneration follows only for the lucky few for whom a whole series of fortuities coalesce-from the preservation of the biological evidence after conviction to the inmate's ability to attract assistance of counsel at a point in the proceedings when the convicted usually have no right to appointed counsel. ${ }^{33}$

Attempts have been made to more fully count wrongful convictions based on all types of evidence, not just DNA evidence, and to estimate a rate of wrongful convictions. ${ }^{34}$ While both the total number of wrongful convictions and the rate of wrongful convictions are unknowable, serious estimates typically put the rate in the range of 0.5 percent $^{35}$ to five percent or more, ${ }^{36}$ and the number of wrongful convictions each year in the thousands to tens of thousands. ${ }^{37}$

Thus, the wrongful convictions cases have made it clear that we have a problem. As Dan Simon concluded recently after extensive analysis of the adjudicative process, "in difficult and contested criminal cases, the adjudicative process falls short of

31. See Innocence Project, www.innocenceproject.org (last visited Oct. 25, 2011); Brandon L. Garrett, Judging Innocence, 108 Colum. L. Rev. 55 (2008); Findley, supra note 25.

32. See Garrett, supra note 31, at 62; Daniel S. Medwed, The Zeal Deal: Prosecutorial Resistance to PostConviction Claims of Innocence, 84 B.U. L. Rev. 125, 126 (2004); Sandra Guerra Thompson, Judicial Blindness to Eyewitness Misidentification, 93 Mare. L. Rev. 639, 639 (2009).

33. Capital cases are a limited exception to this rule because laws in many capital jurisdictions provide a right to appointed counsel in collateral proceedings in death cases. See Eric M. Freedman, Giarratano Is a Scarecrow: The Right to Counsel in State Capital Postconviction Proceedings, 91 Cornell L. Rev. 1079, 1086-87 (2006) (observing that thirty-three of the thirty-seven death penalty states provide a statutory right to counsel in capital postconviction proceedings).

34. E.g., Gross et al., supra note 2; Samuel R. Gross \& Barbara O’Brien, Frequency and Predictors of False Conviction: Why We Know So Little, and New Data on Capital Cases, 5 J. Empirical Legal Stud. 927, 946-47 (2008); C. Ronald Huff et al., Guilty Until Proved Innocent: Wrongful Conviction and Public Policy, 32 Crime \& Deline. 518 (1986); D. Michael Risinger, Innocents Convicted: An Empirically Justified Wrongful Conviction Rate, 97 J. Crim. L. \& Criminology 761, 778-79 (2007).

35. Huff et al., supra note 34 , at 520-24.

36. Risinger, supra note 34 , at 778-79.

37. Keith A. Findley, Defining Innocence, 74 Alb. L. Rev. 1157 (2011); Gross et al., supra note 2, at 551; George C. Thomas III, What's Wrong with the Criminal Justice System and How We Can Fix It, 7 Оніо St. J. CRiм. L. 575, 577-78 (2010) (noting that a two percent error rate would produce 40,000 wrongful felony convictions each year); Marvin Zalman, An Integrated Justice Model of Wrongful Convictions, 74 Alb. L. Rev. 1465, 1473 (2011). 
delivering the level of diagnosticity that befits its epistemic demands and the certitude that it proclaims." ${ }^{38}$ Any wrongful convictions are problematic, and we now know we have more than just a few. Whatever the total, it is well above insignificant or tolerable levels. We can never, of course, achieve perfection in our truth-seeking. But the growing number of identified wrongful convictions at least requires us to consider a fundamental question: Can we do better? And indeed, it is clear we can do better. ${ }^{39}$

\section{III. “INNOCENCE PROCEDURES"}

The innocence cases $^{40}$ have already provided initial insights and impetus for doing better. Study of the DNA exonerations, in particular, has identified recurring sources of error in criminal cases, and corresponding reforms to address those errors. Those insights and reforms have focused on a "canonical" list ${ }^{41}$ of causes of false convictions, including eyewitness identification error, ${ }^{42}$ false confessions, ${ }^{43}$ forensic science error, ${ }^{44}$ false jailhouse informant testimony, ${ }^{45}$ police and prosecutor misconduct, ${ }^{46}$ inadequate defense counsel, ${ }^{47}$ and tunnel vision. ${ }^{48}$

38. Simon, supra note 24 , at 146.

39. See Keith A. Findley, Toward a New Paradigm of Criminal Justice: How the Innocence Movement Merges Crime Control and Due Process, 41 Tex. Tесн L. Rev. 133 (2008).

40. By "innocence cases" I mean those cases in which a factually innocent person was wrongly convicted. Most prominent among these cases are those in which the defendant's innocence was proved beyond reasonable dispute by postconviction DNA testing. While the DNA cases are the clearest examples of "innocence cases," they do not represent all, or probably even most, cases in which factually innocent people were wrongly convicted. See Findley, supra note 37.

41. Samuel R. Gross, Convicting the Innocent, 4 Ann. Rev. L. \& Soc. Sci. 173, 186 (2008).

42. See Gary L. Wells, Eyewitness Identification: Systemic Reforms, 2006 Wis. L. REv. 615; John Turtle et al., Best Practice Recommendations for Eyerwitness Evidence Procedures: New Ideas for the Oldest Way to Solve a Case, 1 Can. J. Police \& Security Services 5 (2003).

43. See Saul M. Kassin et al., Police-Induced Confessions: Risk Factors and Recommendations, 34 Law \& Hum. Benav. 3 (2010); Steven A. Drizin \& Richard A. Leo, The Problem of False Confessions in the Post-DNA World, 82 N.C. L. REv. 891, 906-07 (2004).

44. See Brandon L. Garrett \& Peter J. Neufeld, Invalid Forensic Science Testimony and Wrongful Convictions, 95 VA. L. Rev. 1 (2009).

45. See Alexandra Natapoff, Snitching: Criminal Informants and the Erosion of American Justice (2009); Alexandra Natapoff, Beyond Unreliable: How Snitches Contribute to Wrongful Convictions, 37 Golden Gate U. L. Rev. 107 (2006).

46. See Peter A. Joy, The Relationship Between Prosecutorial Misconduct and Wrongful Convictions: Shaping Remedies for a Broken System, 2006 WIs. L. Rev. 399; Ellen Yaroshefsky, Wrongful Convictions: It Is Time to Take Prosecution Discipline Seriously, 8 UDC/DCSL L. Rev. 275 (2004); Kathleen Ridolfi \& Maurice Possley, Preventable Error: A Report on Prosecutorial Misconduct in California 1997-2009 (2010), http://law.scu.edu/ncip/file/ProsecutorialMisconduct_BookEntire_online\%20version.pdf.

47. Adele Bernhard, Effective Assistance of Counsel, in Wrongly Convicted: Perspectives on Failed Justice 220, 226 (Saundra D. Westervelt \& John A. Humphrey eds., 2001).

48. See Findley \& Scott, supra note 21, at 292; Dianne L. Martin, Lessons About Justice from the "Laboratory" of Wrongful Convictions: Tunnel Vision, the Construction of Guilt and Informer Evidence, 70 UMKC L. REv. 847 (2002). 
ADVERSARIAL INQUISITIONS: RETHINKING THE SEARCH FOR THE TRUTH

\section{A. Nerw Ways of Approaching Innocence}

In addition to reforming the way we collect and use these specific types of evidence, scholars have begun to suggest broader reforms to the procedures used to investigate and litigate cases where the accused claims to be factually innocent. ${ }^{49} \mathrm{~A}$ number of scholars have proposed adopting special "innocence procedures," which can be invoked by the defendant who claims actual innocence. Among those are proposals by Tim Bakken ${ }^{50}$ and Lewis Steel, ${ }^{51}$ as well as Michael Risinger, ${ }^{52}$ most recently joined in an expanded proposal by Lesley Risinger. ${ }^{53}$

Michael Risinger initially proposed a set of "factual innocence rules," applicable in cases in which the defendant asserted a claim of factual innocence-that is, a claim that she did not commit the acts alleged. ${ }^{54}$ Risinger "tentatively" suggested that this procedure might include a series of new procedures designed to minimize the harmful effects of many of the types of evidence known to cause wrongful convictions. In particular, he would require the defendant to identify one or two particular disputed facts that underlie her claim of innocence, and to remove all other issues by binding judicial admission, so as to eliminate the need or opportunity for extraneous "heartstrings and gore" testimony on matters not even in dispute. ${ }^{55} \mathrm{He}$ would also require careful screening of prosecution expert testimony for reliability, and would prevent the court "from excluding, on the ground of 'invasion of the province of the jury,' any defense-proffered expert evidence on the weaknesses of eyewitness identification, false confessions, the commonness of false testimony by jailhouse snitches, and the weaknesses of any expert evidence proffered by the prosecution." ${ }^{" 56}$ And he would limit closing arguments to the factual issues raised in the defendant's innocence application. Finally, Risinger would mandate an expanded scope of appellate review for factual error, providing that convictions would be

49. It is a popular misconception that everyone in prison claims to be innocent. More than ninety-five percent of all convicted individuals plead guilty or no contest to the charges against them. See, e.g., Thomas H. Cohen \& Tracey Kyckelhahn, U.S. Dep't of Justice, Felony Defendants in Large Urban Counties, 2006 (2010), http://bjs.ojp.usdoj.gov/content/pub/pdf/fdluc06.pdf. While some of these defendants plead guilty while persisting in a claim of innocence, most do not. See A. E. Воттомs \& J.D. McClean, Defendants in the Criminal Process 120 (1976). Guilt or innocence is not the dominant issue in most criminal cases; Richard V. Ericson \& Patricia M. Baranek, The Ordering of Justice: A Study of Accused Persons as Defendants in the Criminal Process 158 (1982).

50. Bakken, supra note 3.

51. Steel, supra note 3.

52. Risinger, supra note 3.

53. Risinger \& Risinger, supra note 3.

54. Risinger, supra note 3, at 1311-13.

55. Id. at 1313.

56. Id. at 1311-12 (footnotes omitted). 
reviewable not just for sufficiency of the evidence but also to determine whether they were "unsafe." 57

Tim Bakken subsequently proposed a different set of "innocence procedures" specifically designed to redress features of the adversary process that undermine truth-seeking. Like Risinger, Bakken would reserve his procedure for inmates who make a special plea of factual innocence. ${ }^{58}$ In such cases, Bakken's system would then depend on a prosecutor who is specially charged, except in exceptional circumstances, ${ }^{59}$ to look for evidence of innocence as well as guilt. ${ }^{60}$ In this sense, Bakken's proposal shares features of a proposal made some years earlier by Lewis Steel, who argued that prosecutors should establish "innocence bureaus" to handle cases in which the defendant claims actual innocence. ${ }^{61}$

Bakken, like Steel, thus proposes a bifurcated system in which inmates could choose either to proceed in the traditional adjudication track or to plead "innocent" and participate in a special system designed to focus on truth-finding. The features of this special innocence procedure would include the following:

- The defendant who pleads "innocent" would be entitled to a prosecutor acting in some sense as inquisitor-in the best sense of the word-who "would be required, absent a compelling justification, to faithfully investigate the truth of defendants' innocence claims, as opposed to focusing on determining whether guilt can be proven beyond a reasonable doubt." ${ }^{2}$

- The prosecutor would be required to prove guilt by a heightened standard of proof-higher than beyond a reasonable doubt, to a virtual certainty. ${ }^{63}$

- "Jurors could infer innocence from an innocent plea[.]" ${ }^{64}$

57. Id. at 1312. The term "unsafe" is borrowed from British procedure, which provides relief upon review for "unsafe" convictions, a form of review that might be viewed as somewhat analogous to weight-ofthe-evidence review, but with teeth. Id. at 1314-15.

58. Bakken, supra note 3 , at 549 .

59. In Bakken's terms, “absent compelling justification.” Id. at 549.

60. Id. at 549 .

61. Steel, supra note 3. Steel proposed that, "[w]hile prosecutors pursue convictions, the innocence bureau would seek justice." Id.

62. Bakken, supra note 3 , at 549 .

63. Id. Bakken suggests that "[t]his standard might encompass guilt to a moral certainty, or as proposed in the sentencing phase of capital cases, to an absolute certainty, proof beyond all reasonable doubt, or to a similarly high standard." Id. at 574-75 (footnotes omitted).

64. Id. at 549 . 
ADVERSARIAL INQUISITIONS: RETHINKING THE SEARCH FOR THE TRUTH

- "Jurors could draw inferences favorable to the defendant from the defendant's prompt claim of innocence[.]"

- "Jurors could presume that evidence and leads presented by the defendant but not pursued by the government would have been favorable to the defendant[.]"66

Under Bakken's scheme, in return for these benefits, the defendant who pleads "innocent" would agree to cooperate with the prosecution, thus revealing virtually his entire defense and waiving his Fifth Amendment and Sixth Amendment privileges to silence and confidentiality ${ }^{67}$ Similarly, Steel's proposal would require defendants who seek the advantages of his special "innocence bureaus" to "agree to be interrogated by [innocence] bureau attorneys and allow these interviews to be used against them in court if their claims of innocence were rejected. And defense attorneys would have to turn over all their clients' evidence." ${ }^{6}$

\section{B. The Critique: Both Too Much and Too Little}

These proposals are challenging and enlightening, and they offer an important starting point for reimagining a criminal justice system truly focused on truthfinding. As would be expected with an enterprise as ambitious as one that seeks to redesign the system for adjudicating questions of guilt and innocence that we have inherited and largely accepted as a given, these reform proposals are controversial, and necessarily preliminary and hence imperfect.

I begin my own inquiry into the rhetorical question posed at the outset of the article- how best to design a system to find the truth - with the benefit of drawing on the proposals already made. Those proposals give me the luxury of reacting first to the suggestions of others, and then building on them to theorize my own idealized truth-finding system.

My reaction to these (especially Bakken's and Steel's) initial proposals for "innocence procedures" is that in significant respects they just tweak the existing system - they superimpose some inquisitorial procedures onto the framework of a polarized adversary culture and hope for the best. Indeed, Risinger, at least to some extent, would agree, as his more recent proposal, proffered jointly with Lesley Risinger, builds upon his prior work and now recommends additional, more extensive reforms, as discussed below. ${ }^{69}$ In the discussion that follows, I explain my concerns about the limitations of these initial proposals and develop my own tentative suggestions for doing more.

65. Id. at 550 .

66. Id.

67. Id. at 549 .

68. Steel, supra note 3.

69. Risinger \& Risinger, supra note 3. 
Bakken and Steel deserve considerable credit for expanding the discussion on new ways of thinking about innocence. As noble as their venture is, however, I have serious doubts that it would alter all that much in terms of making the system more reliable. At the same time, it might require more change than is necessary or useful. Thus, their proposals both go too far and not nearly far enough.

Requiring prosecutors to "faithfully investigate the truth of defendants' innocence claims, as opposed to focusing on determining whether guilt can be proven beyond a reasonable doubt," ${ }^{\prime 0}$ for example, would be unlikely to change much in the way the process currently operates. American prosecutors would say they already do that. ${ }^{71} \mathrm{It}$ is not clear how telling or even training prosecutors to change their behavior would have any effect on how they actually behave. As discussed more fully below, even in Continental systems steeped in a tradition of prosecutorial neutrality, prosecutors sometimes fail to investigate impartially in practice. ${ }^{72}$ The challenge would be far greater in the United States, with its tradition and culture of adversariness.

Requiring proof of guilt to a higher standard than beyond a reasonable doubt also would not likely improve truth finding. Paul Cassell objects to this proposal because it would, he fears, change too much - it would make conviction virtually impossible. ${ }^{73}$ Cassell is correct about that, but only if jurors were to apply that high standard of proof rigorously and literally. My concern comes from a different place. I suspect that it is more likely that Bakken's heightened standard of proof will not change much of anything. There is good evidence that jurors do not rigorously apply the proof-beyonda-reasonable-doubt standard, ${ }^{74}$ and it is not clear how to formulate a higher standard

70. Bakken, supra note 3 , at 549 .

71. It is already widely accepted that American prosecutors are tasked with dual roles: zealous advocate and minister of justice. In the latter role, prosecutors are already expected to fully seek the truth, including investigating the truth of defendants' innocence claims. See Model Rules of Prof'l Conduct R. 3.8 cmt. 1 (2006) (stating that the prosecutor "has the responsibility of a minister of justice and not simply that of an advocate"); Model Code of Prof'l Responsibility EC 7-13 (1980) (stating that a prosecutor's duty "is to seek justice, not merely to convict"); Standards for Criminal Justice: Prosecution Function \& Def. Function § 3-1.2(c) (3d ed. 1993) (also stating that a prosecutor's duty "is to seek justice, not merely to convict"); Abby L. Dennis, Reining in the Minister of Justice: Prosecutorial Oversight and the Superseder Power, 57 Duke L.J. 131, 138-39 (2007).

72. Martin Killias, Wrongful Convictions in Switzerland: The Experience of a Continental Law Country, in Wrongful Convictions, supra note 13, at 145-48 (citing examples from Switzerland in which failure of prosecutors to investigate impartially contributed to wrongful convictions); see infra notes 108, 11318 and accompanying text.

73. Paul G. Cassell, Freeing the Guilty Without Protecting the Innocent: Some Skeptical Observations on Proposed New "Innocence" Procedures, 56 N.Y.L. Sch. L. Rev. 1063 (2011-12).

74. See Findley \& Scott, supra note 21, at 340-41; Michael J. Saks \& D. Michael Risinger, Baserates, the Presumption of Guilt, Admissibility Rulings, and Erroneous Convictions, 2003 Мгсн. Sт. L. Rev. 1051, 1061-62; see also Simon, supra note 24, at 196-97 (explaining how cognitive processes such as the "coherence effect" can create confidence inflation that "can boost a mere leaning towards conviction up to a highly confident judgment of guilt that surpasses the requisite threshold for conviction"). Simon also observes that empirical research reveals that "both judges and jurors tend to vote to convict even when they deem the inculpatory evidence to be less than compelling." Id. at $202 \mathrm{n} .253$ (citing Theodore Eisenberg et al., Judge-Jury Agreement in Criminal Cases: A Partial Replication of Kalven and Zeisel's The American Jury, 2 J. Empirical Legal Stud. 171, 186-87 (2005)). 
that would have more teeth. Changing the jurors' instructions about how certain they should be before they convict probably would not mean much.

Instructing jurors that they may infer innocence from an innocent plea also would be unlikely to change much. Jurors already are told to begin with a presumption of innocence whenever a defendant pleads not guilty. It is hard to imagine how this additional instruction would add to that in any significant way. Quite simply, it is unlikely that such an instruction would change the way jurors approach their resolution of cases.

Similarly, permitting jurors to draw inferences favorable to the defendant from the defendant's prompt claim of innocence also would not likely change much. Such an inference is already permissible, and defense lawyers routinely argue that a defendant's prompt and consistent claims of innocence support acquittal. Bakken's inference would be reinforced by a jury instruction, but it is not clear that such an instruction would change anything at all in the way jurors approach their decisionmaking. Moreover, such an instruction could actually harm truth-seeking for some innocent defendants. Any defendant who invokes her right to remain silent upon arrest would conceivably be punished under this presumption for having failed to make a prompt claim of innocence. Yet the Supreme Court has repeatedly observed that any invocation of silence, especially after one has received Miranda $a^{75}$ warnings, cannot be evidence of guilt, because it is "insolubly ambiguous." 76

Finally, Bakken's rule permitting jurors to presume that evidence and leads presented by the defendant but not pursued by the government would have been favorable to the defendant also would not change much. Again, such a presumption is already possible, even if not officially acknowledged. A common defense tactic under the current system is to challenge the thoroughness, objectivity, and competence of the police investigation, ${ }^{77}$ and jurors are routinely urged to infer that the results of a more complete investigation would have helped the defense. If truth is the goal, it would be far better, instead of instructing juries that they can infer exculpatory evidence, to impose rules to ensure that all legitimate investigative leads are pursued from the beginning so that it would be unnecessary to speculate about what the leads would have produced. In fairness, Bakken's rule with its jury instruction might produce the needed inducement to get police and prosecutors to investigate more thoroughly to avoid the jury instruction. But more directly entitling the defendant to a full investigation, as discussed below, would seem to serve that interest more fully.

At the same time, the concessions that Bakken proposes the defense should make would not necessarily serve the interest of finding the truth, and would require too much from an accused person in return. A full search for the truth might indeed require the defendant to waive some confidentiality rules—-so that both sides would

75. Miranda v. Arizona, 384 U.S. 436 (1966).

76. Doyle v. Ohio, 426 U.S. 610, 617 (1976) (“[E]very post-arrest silence is insolubly ambiguous because of what the State is required to advise the person arrested.”).

77. See Kyles v. Whitney, 514 U.S. 419, 446 (1995) ("A common trial tactic of defense lawyers is to discredit the caliber of the investigation ...." (quoting Bowen v. Maynard, 799 F.2d 593, 613 (10th Cir. 1986) (internal quotation mark omitted))). 
have access to all of the evidence in advance of trial. If, as posited at the outset, trial by ambush is antithetical to effective adversarial truth-development, then neither side should be permitted to hide its cards before trial. But even that rationale does not justify requiring full waiver of confidentiality, thereby sacrificing all of the protections designed to ensure that accused individuals will feel free to share information fully with their lawyers. Indeed, extensive waiver of confidentiality would likely interfere with the search for the truth by stifling the free flow of information between defendant and counsel.

Moreover, although requiring defendants to waive their right to silence, and to submit to questioning by police and prosecutors, is often assumed to lead to a fuller exposition of the truth, that is far from obviously so. The right against compelled self-incrimination is not necessarily a truth-obscuring rule; to the contrary, it often adds to truth-finding in significant ways. The right to silence does not just protect the guilty. It also protects the innocent. ${ }^{78}$

The primary purpose of requiring testimony from a criminal defendant who claims innocence is to test that testimony for veracity. To invoke special innocence procedures, a defendant must deny guilt. Any testimony the defendant might offer will thus be inconsistent with the prosecutor's evidence of guilt. The purpose for requiring the defendant to testify under those circumstances would be to test the defendant's testimony for its veracity and completeness. Scrutinizing the veracity of the defendant's testimony, however, would not likely contribute much of value to the search for the truth. Extensive research establishes that judges, juries, and police alike do not perform well at detecting deceit; they typically perform at little better than chance levels. ${ }^{79}$ Many of the signals people look for to detect deceit-either by intuition or training-are not empirically correlated to lie detection. ${ }^{80}$ Nervousness, gaze aversion, fidgeting, and the like can be caused by a host of factors and are not uniquely diagnostic of lying. ${ }^{81}$ Yet a nervous or fidgety witness is typically deemed less trustworthy than a composed witness. Assessing the veracity of a defendant's

78. A law and economics analysis similarly suggests that the right to silence can protect the innocent. Under that analysis, the right to silence is essentially meaningless in cases with either very strong or very weak proof of guilt, because the defendant's testimony is unlikely to make a difference in the outcome in either case. The right to silence will have an effect in cases where the evidence of guilt is strong, but not overwhelming. In those cases, if there were no right to silence, guilty and innocent defendants alike would have no choice but to testify, and guilty ones would have no choice but to lie. The result would be an overall devaluing of exculpatory defendant testimony, as factfinders would discount the likelihood of veracity. Innocent defendants who testify would be less likely to be believed. But with a right to silence, some guilty defendants will find it more attractive not to testify at all, and the testimony of innocent defendants would suffer less of a discount. "The externality that [guilty defendants who testify falsely] otherwise would impose upon innocents (the pernicious pooling effect) will thus be eliminated. As a result, fewer innocent defendants will be convicted than under a regime in which the right to silence does not exist." Alex Stein, SelfIncrimination, in Procedural Law and Economics § 2.1 (Chris W. Sanchirico ed., 2011) (Encyclopedia of Law and Economics, Vol. X, Gerrit De Geest ed., 2d ed. 2009-2011), available at http://works.bepress.com/cgi/viewcontent.cgi?article=1021\&context=alex_stein.

79. See Simon, supra note 24, at 177; Kassin et al., supra note 43, at 6.

80. Kassin et al., supra note 43 , at 6 .

81. Id. 


\section{ADVERSARIAL INQUISITIONS: RETHINKING THE SEARCH FOR THE TRUTH}

testimonial claim of innocence thus would be about as likely to lead to fact-finding error as accuracy.

Indeed, the risk of misconstruing witness behavior as deceit is especially profound for innocent defendants. ${ }^{82}$ As Dan Simon has observed, "the research suggests that the motivation to be believed tends to increase suspicious behaviors and thus reduces one's believability, regardless of the truthfulness of the testimony." ${ }^{83}$ An innocent defendant, as an obviously self-serving witness pleading his innocence, will often come off badly, thereby undermining the search for the truth. Liars often can be more believable than accused innocents: "Unlike truth-tellers, liars tend to try to control their behavior to feign normal demeanor. Liars also expend extra cognitive effort to keep their stories straight and to monitor their apparent believability." ${ }^{84}$ Thus, in the courtroom, "most witnesses-innocent defendants perhaps more than others - are anxious to be believed by the jury. Jurors might well misconstrue signs of nervousness as signs of deceit." 85

Moreover, even more so than other witnesses, the innocent defendant will have her statements or testimony scrutinized for any inconsistencies or omissions. Even the most innocuous or understandable slip-ups will be magnified and cast as evidence of guilt. While inconsistencies in any witness's testimony will be analyzed by the adverse party, rarely does a focus on the manner of testifying carry such risk of prejudice with other witnesses as it does with an innocent defendant; rarely does a jury consider such witnesses to be as inherently motivated to fabricate, and rarely does a jury's assessment of credibility so directly prejudice the person on trial. While sometimes testimonial errors of the accused will indeed reflect guilt, they will also frequently suggest nothing more than the foibles of human memory and expression to which we are all prone-foibles that can be amplified by the innocent defendant's intense motivation to be believable and attendant nervousness.

Furthermore, as James Duane has argued in a popular and entertaining online lecture, whenever even the innocent defendant talks to police, and even if he gives police nothing but the truth, he inevitably provides information that can be used to

82. Bakken himself recognizes this risk. He notes that,

[i]n an odd twist, the innocent defendant who testifies will often be punished for doing so. That is, the prosecution may request that the judge instruct the jury that the defendant who testifies is an "interested witness," thus implying that the defendant, despite being innocent, is less likely to be truthful.

Bakken, supra note 3, at 556.

83. Simon, supra note 24, at 178-79 (citing Bond \& DePaulo, supra note 24, at 226-27); see also Christian A. Meissner \& Saul M. Kassin, "You're Guilty So Just Confess!" Cognitive and Behavioral Confirmation Biases in the Interrogation Room, in Interrogations, Confessions, and Entrapment 85, 95 (G. Daniel Lassiter ed., 2004); Mikah K. Story Thompson, Methinks the Lady Doth Protest Too Little: Reassessing the Probative Value of Silence, 47 U. Louisville L. Rev. 21, 42 (2008) ("A suspect facing [aggressive interrogation] tactics will likely become more nervous and defensive, thereby confirming the investigator's initial belief that the suspect is guilty.").

84. Simon, supra note 24 , at 175.

85. Id. at 179 . 
convict him; every suspect unavoidably makes innocuous and innocent statements that can be cast as incriminating, or that can be challenged by other evidence-even false or unreliable evidence. ${ }^{86}$ As the Supreme Court declared in Ohio v. Reiner, "one of the Fifth Amendment's basic functions . . . is to protect innocent men . . . who otherwise might be ensnared by ambiguous circumstances. ... [T]ruthful responses of an innocent witness, as well as those of a wrongdoer, may provide the government with incriminating evidence from the speaker's own mouth." ${ }^{87}$ Once the defendant puts his credibility on the line by providing a statement and once his credibility is impeached-whether correctly or not-the likelihood of conviction soars.

Forcing a defendant to waive the right to silence thus does not necessarily, or even probably, aid the search for the truth. At a minimum, without solid evidence that such a waiver is essential to full and reliable access to the truth, defendants should not be required to waive such an important constitutional right.

\section{Beyond the "Neutral Prosecutor"}

Most fundamentally, the procedures that Bakken and Steel propose do not accomplish the ends they seek because they offer too little too late. Aside from encouraging prosecutors to fully investigate claims of innocence, they do little else to address the investigative stages of the process, when the outcome of most cases is determined.

Because the outcome of most cases is set by the time the investigation is concluded, more attention must be paid to that initial stage. Indeed, despite the rhetoric in America about the truth-finding value of adversarial litigation, actual adversarial testing of the evidence is rare, because the incidence of jury trials is quite low. ${ }^{88}$ Most cases-more than ninety-five percent-are resolved by pleas. ${ }^{89}$ In this sense, police and prosecutors are already inquisitors. But they are inquisitors profoundly affected by the culture of adversariness.

Michael and Lesley Risinger address that shortcoming by proposing an investigating magistrate. ${ }^{90}$ They note, correctly, that under the current American system,

86. James Duane, Don't Talk to Cops, Part 1, YouTube (June 10, 2008), http://www.youtube.com/ watch?v=i8z7NC5sgik.

87. Ohio v. Reiner, 532 U.S. 17, 20 (2001) (first and second alterations in original) (internal quotations omitted); see also Akhil Reed Amar \& Renee B. Lettow, Fifth Amendment First Principles: The SelfIncrimination Clause, 93 Мich. L. Rev. 857, 904 (1995) ("The Self-Incrimination Clause, as best read, is designed to protect a truly innocent defendant who might be made to look guilty on the stand by a clever prosecutor skilled in technical courtroom procedure and forensics. To infer guilt from mere in-court silence would seem to betray the innocent but unpersuasive defendant whom the clause seeks to protect.").

88. Gerald S. Reamey, Innovation or Renovation in Criminal Procedure: Is the World Moving Toward a New Model of Adjudication?, 27 Ariz. J. InT'L \& Comp. L. 693, 708 (2010).

89. Marc Galanter, The Vanishing Trial: An Examination of Trials and Related Matters in Federal and State Courts, 1 J. Empirical Legal Stud. 459, 495 (2004).

90. Somewhat more modestly, George Thomas has proposed that investigations into one particular type of especially problematic evidence be supervised not by police but by a judicial officer: eyewitness identifications. Thomas, supra note 17, at 579. 
ADVERSARIAL INQUISITIONS: RETHINKING THE SEARCH FOR THE TRUTH

[t]he police, and then the prosecution in cooperation with the police, have a monopoly on information gathering and assembly (vel non) in secret until a charging decision is made. By the time any effective adversary involvement comes about, the most important part of the case is often (or even usually) over. ${ }^{91}$

In addition, recognizing the risk that the investigative magistrate might be captured by police and prosecutorial interests, they also advocate for early involvement of adversary representation and for passing the responsibility for the process to the adversary parties once a charging decision is made. ${ }^{92}$ Once the charging decision is made, they suggest, "the entire results of investigation, including the investigatory personnel (detectives, forensic scientists, forensic pathologists, etc.), would become available to both the prosecution and defense for consultation, and for the potential conduct of follow-up investigation or testing suggested to the magistrate by either the prosecutor or the defense attorney." 93

This approach offers considerable promise, to the extent that it expands the scope of the investigation and removes it from the control of one party in our adversarial process. But this proposal is also not problem free. To begin with, some scholars question whether the American judiciary can be expected to shoulder such responsibility. Marvin Zalman argues: "Creating an investigating magistrate role in the United States is impossible. The separation of powers is not the only reason. American judges, elected or appointed from the diverse world of law practice, simply have no expertise in such a role." 94

More fundamentally, even a truly neutral magistrate cannot be expected to investigate fully all of the evidence that might prove innocence. Cognitive biases such as confirmation bias, along with public law-and-order pressures, are simply too powerful. ${ }^{95}$ The many cases in which judges have turned down post-conviction DNA test requests-even when the DNA testing indisputably could (and sometimes eventually did) prove innocence-confirm that even objective magistrates or judges can be led astray and can fail to entertain the possibilities of exculpatory evidence even when they are real. ${ }^{96}$ Risinger and Risinger, recognizing this, wisely seek to

91. Risinger \& Risinger, supra note 3, at 884-85.

92. Id. at 885 .

93. Id. at 893 .

94. Marvin Zalman, The Adversary System and Wrongful Convictions, in Wrongful Convictions, supra note 13 , at 86 .

95. See Findley \& Scott, supra note 21, at 307-31.

96. See Dist. Attorney's Office for the Third Judicial Dist. v. Osborne, 129 S. Ct. 2308 (2009); Godschalk v. Montgomery Co. Dist. Attorney's Office, 177 F. Supp. 2d 366 (E.D. Pa. 2001). In Godschalk, the state court judge initially denied Godschalk's petition for DNA testing because the judge believed the evidence of guilt was so overwhelming that there was no point in doing DNA testing. Id. at 367. After the federal district court ordered the testing on the "remote" chance that the testing would exonerate Godschalk, the DNA testing did just that, and Godschalk was freed. Access to Postconviction DNA Testing, Innocence Project, http://www.innocenceproject.org/Content/Access_To_PostConviction_ DNA_Testing.php (last visited Oct. 25, 2011). 
inject adversarial scrutiny and control into the investigative process as early as possible - that is, as soon as the defendant is charged. But is even that enough?

\section{ADVERSARY INQUISITIONS: HARNESSING THE POWER OF BOTH SYSTEMS}

While Risinger and Risinger are on the right track, I want to find ways to harness the power of adversarial testing throughout the process to ensure that the unavoidably inquisitorial initial investigation is indeed responsive to the interests of both sides, and hence to the truth. The system I envision is one that seeks to take advantage of the strengths, while minimizing the weaknesses, of both the adversarial and inquisitorial models. Before describing my own alternative, a caveat is in order: my focus here is solely on pretrial and trial procedures; appellate and post-conviction review procedures are beyond the scope of this article. They are matters I (and others) have addressed elsewhere. ${ }^{97}$

\section{A. Adversarial and Inquisitorial Strengths and Weaknesses}

An inquisitorial system is said to be more focused on truth-finding than the adversarial system. ${ }^{98}$ Inquisition advocates often assert that "criminal procedure that relies on professional judges of fact and an impartial, state-appointed prosecutor (i.e., an inquisitorial system such as exists in the Netherlands) probably produces fewer miscarriages than a procedure built around autonomous parties, a jury, and partisan (and sometimes elected) prosecutors as in the adversarial system." ${ }^{.99}$ In part, that is because "the adversarial system places greater emphasis on the process than on simple truth-finding." 100 Marvin Zalman has thus advanced "the hypothesis that the adversary process itself is a contributor to erroneous convictions." 101

Much of the problem, as already noted, is that the outcome of a case is usually determined long before trial (or plea), that is, at the administrative investigation stages. If truth and reliability are the objectives, therefore, what really must be done is improve the quality of the evidence gathering and interpreting at the initial investigation stages. ${ }^{102}$ Daniel Givelber argues, however, that the American adversarial and constitutional-rights-based jurisprudence has ignored the features of a criminal justice system that best assure truth finding:

97. Findley, supra note 25; Risinger, supra note 3; Risinger \& Risinger, supra note 3.

98. For a description of the various features of the inquisitorial system that distinguish it from the adversary system, see Mirjan Damaška, The Faces of Injustice and State Authority: A Comparative Approach to the Legal Process (1986).

99. See Chrisje Brants, The Vulnerability of Dutch Criminal Procedure to Wrongful Conviction, in Wrongful Convictions, supra note 13 , at 159 .

100. Huff, supra note 13 , at 65 .

101. Zalman, supra note 94 , at 76.

102. Findley, supra note 11; see also Simon, supra note 24, at 202-03 ("[C]riminal verdicts are determined to a large degree at the investigative phase, with the trial serving primarily as a ritual that delivers more symbolic than real value."). 


\section{ADVERSARIAL INQUISITIONS: RETHINKING THE SEARCH FOR THE TRUTH}

But the [Supreme] Court has refused to concern itself with the obligations of the police or prosecutor to conduct a thorough investigation, to maintain comprehensive records, or even to choose wisely which potential defendants to charge. These matters - the very essence of a system concerned with actual innocence-are extra-constitutional. ${ }^{103}$

All of this might be interpreted to suggest that an inquisitorial system, expressly focused on neutral examination of the facts to find the truth, offers a better path to accurate assessment of claims of innocence. The inquisitorial system, however, is only superior in this regard if the inquisitorial model takes hold early in the processbefore the investigation seals the defendant's fate-and only if the inquisitor truly can remain neutral and objective, and indeed, can aggressively pursue evidence supporting innocence. Thus, in an inquisitorial system, "both the legitimacy of criminal justice and the fate of the individual in terms of fair trial depend to a large extent on the integrity of state officials and their visible commitment to nonpartisan truth finding." 104 Moreover, the inquisitorial system is superior only to the extent that the prosecutor (or magistrate) has the incentives and fortitude to second-guess even her own initial suspicions and judgments and to see facts from multiple perspectives - a very tall order indeed.

To expect a career prosecutor-or even a judge or magistrate-drawn from our current sharply adversarial system and culture to be able to play that role is to expect too much. The adversary culture we have inherited is deep and pervasive, and "adversarialness breeds a competitive spirit among prosecutors that leads to withholding evidence ...." 105 William Pizzi, who has criticized the American system for producing "trials without truth," argues that a "conviction mentality" motivates prosecutors to privilege securing convictions over achieving justice or truth-seeking. ${ }^{106}$ Thus, Zalman notes that "[a]t least one leading scholar has warned against making quick judgments about the superiority of one system over the other and of thinking that it is easy to transplant procedures from one 'system' into another." ${ }^{107}$

103. Daniel Givelber, Meaningless Acquittals, Meaningful Convictions: Do We Reliably Acquit the Innocent?, 49 Rutgers L. Rev. 1317, 1371 (1997) (footnotes omitted). That all may be beginning to change. Darryl Brown contends that the "weakness of adversarial adjudication" is beginning to produce a new model that focuses more on administrative processes and investigative integrity. See Darryl K. Brown, The Decline of Defense Counsel and the Rise of Accuracy in Criminal Adjudication, 93 Calif. L. Rev. 1585, 1591 (2005).

104. Brants, supra note 99 , at 161.

105. Zalman, supra note 94 , at 80 (citing Givelber, supra note 103).

106. Pizzi, supra note 1, at 131-34, 221. Reflective of that "conviction mentality," one district attorney's office recently revealed that it paid its prosecutors financial bonuses for obtaining convictions. Debra Cassens Weiss, Defense Lawyer Subpoenas Docs Detailing Prosecutor's Cash Bonuses for Convictions, A.B.A. J. (Mar. 29, 2011, 5:53 AM), http://www.abajournal.com/news/article/defense_lawyer_subpoenas_ docs_detailing_prosecutors_bonuses_for_convictions/?utm_source=maestro\&utm _ medium=email\&utm_campaign=weekly_email. Likewise, to expect defense attorneys from our current adversarial system and culture to freely share information and to focus on truth-seeking is unrealistic.

107. Zalman, supra note 94, at 79 (citing Mirjan R. Damaška, Evidence Law Adrift (1997); Mirjan Damaška, The Uncertain Fate of Evidentiary Transplants: Anglo-American and Continental Experiments, 45 Ам. J. Сомp. L. 839 (1997)). 
Comparing the role of the American prosecutor to that of the prosecutor in the inquisitorial tradition highlights the magnitude of the challenge of transposing an inquisitorial approach onto the American legal culture. For example, under the German Code of Criminal Procedure (which reflects an inquisitorial system in which a neutral prosecutor is charged with searching for the truth) a German prosecutor "does not function as a party but rather as a "second judge," who functions "from a neutral, detached, and objective perspective." ${ }^{108}$ According to one observer, German prosecutors are seen as "guardians of the law," who "lack the thirst for winning that their American colleagues display in the courtroom." ${ }^{109}$ Indeed, consistent with this role, German prosecutors even present evidence that favors the accused, and at the close of trial are free to recommend an acquittal. ${ }^{110}$ Consistent with this commitment to neutrality, and in stark contrast to American practice, German prosecutors do not meet with the witnesses prior to trial or try to prepare them or the case to be as convincing about the defendant's guilt as possible. ${ }^{111}$ Hence, "[p]erhaps the most striking difference between American and German prosecution practice is that, in contrast with American practice, the majority of German prosecutors do not regard convictions as victories and acquittals as losses." ${ }^{112}$ The role of the prosecutor is similar to the German model in most Continental inquisitorial systems.

Even in other systems that are ostensibly adversarial, the prosecution culture is less partisan and adversarial than in the United States. In Japan, for example, prosecutorial culture is much different than in America. The Japanese system places tremendous responsibility on and confidence in prosecutors to achieve justice, as they are viewed as authorities in the criminal justice system. Defendants have a right to adversarial testing of the evidence, and even a right to remain silent, but defense counsel are typically far more passive than their American counterparts, and defendants are expected to confess (indeed, the conviction rate in Japan is $99.8 \%$, in large part because most defendants confess). ${ }^{113}$ Japanese legal scholar David Johnson explains how Japanese prosecutors function in a culture and pursuant to norms that are vastly different than those in America:

If justice means taking into account the needs and circumstances of individual suspects, then prosecutors in Japan must receive higher marks than their American counterparts. If justice implies treating like cases alike, then the capacity of Japan's procuracy to do so is impressive indeed. If justice should promote healing, not just punishment, then Japanese prosecutors must be

108. Shawn Marie Boyne, Uncertainty and the Search for Truth at Trial: Defining Prosecutorial "Objectivity" in German Sexual Assault Cases, 67 Wash. \& Lee L. Rev. 1287, 1288-89 (2010).

109. Id. at $1290,1302$.

110. Id. at 1303 .

111. Id. at 1316; Langbein, supra note 1 , at 827,834 .

112. Boyne, supra note 108 , at 1304.

113. David T. Johnson, The Japanese Way of Justice 243-44 (2002); Norimitsu Onishi, Pressed by Police, Even Innocent Confess in Japan, N.Y. Times, May 11, 2007, at A3, available at http://www.nytimes. com/2007/05/11/world/asia/11japan.html?pagewanted=print. 
ADVERSARIAL INQUISITIONS: RETHINKING THE SEARCH FOR THE TRUTH

reckoned more restorative than prosecutors in the United States. And if justice depends on uncovering and clarifying the truth, then readers will see how fundamental this maxim is deemed to be in Japan. In these ways and more, the Japanese way of justice is uncommonly just. ${ }^{114}$

Yet even in such a culture, the pressures to convict can be overwhelming. Johnson observes that his account of Japanese prosecutors "uncovers serious defects as well .... [I]n their zeal to obtain the truth through confessions, some prosecutors plea-bargain, doctor dossiers, and conduct brutal interrogations, all actions that are illegal in Japan." 115

Even within the inquisitorial tradition, steeped in its commitment to neutrality and objectivity, it is often too much to expect police and prosecutors to remain truly impartial in every case. Increasingly, inquisitorial systems have witnessed breakdowns when prosecutors succumb to law-and-order pressures and fail to adhere to norms of neutrality. One observer of the Dutch inquisitorial system, for example, has noted that in recent years there have been

significant changes in the way that prosecutors see themselves. Traditionally, the magisterial, nonpartisan prosecutor, able and willing to make 'judicial' decisions in the name of the common good, was the predominant role model ... Gradually this has been replaced among a substantial number of prosecutors by the model of the crime fighter. ${ }^{116}$

Especially in complex and highly publicized cases, both police and prosecutors are "subject to considerable pressure from the media to deliver the goods (i.e., a conviction)." 117 David Johnson has also noted these breakdowns of neutrality in the Dutch inquisitorial system:

While acknowledging that prosecutors try to be "scrupulously fair" and that "their sense of duty to uphold the dignity of their office is beyond doubt," [Dutch journalist Karel] Van Wolferen claims prosecutors do "not accept being shown in the wrong." They are, he agrees with Chalmers Johnson, obstinate, stubborn, and intransigent. Furthermore, prosecutors "want to be God" and are "quite ready to tip the scales of justice out of social considerations."118

If prosecutors in systems with a rich inquisitorial tradition of prosecutorial neutrality are susceptible to such pressures, it is wholly unrealistic to think that prosecutors drawn from America's polarized adversarial system can play the role of neutral inquisitor.

All of this raises serious questions about the workability of Bakken and Steel's "neutral" prosecutor as inquisitor in America. But the problem with an inquisitorial system is deeper than even suggested by the prevailing culture and pressures toward

114. Johnson, supra note 113 , at vii.

115. Id.

116. Brants, supra note 99 , at 171 (citations omitted).

117. Id. at 178.

118. Johnson, supra note 113 , at 6. 
adversarialness in America. The problem also affects the ability of Risinger and Risinger's investigating magistrate to perform the role they assign to her.

Simply assigning investigative responsibility to a neutral magistrate does not ensure a vigorous and unbiased search for the truth. Problems can arise not just when individual prosecutors (or magistrates) succumb to adversarial law-and-order pressures, or fail to adhere to the norms of neutrality. Recent applications of social science research on cognitive processes reveal that even the most well-meaning actors, who are sincerely trying to be objective, are frequently subject to cognitive distortions that make true impartially difficult if not impossible. ${ }^{119}$ Indeed, even in Continental systems with rich inquisitorial traditions, it has been argued that magistrates tend to adopt the attitudes of police and prosecutors. ${ }^{120}$

The strength of the adversary process is that it creates adversarial role players who actively challenge the State's evidence and the State's theory of guilt. In inquisitorial systems, defense counsel play a much weaker role-they lack "the defense rights or adversarial means and skills" and do not conduct their own pretrial investigations. ${ }^{121}$ And neutral judges or magistrates do not fill that role adequately. Instead of adversarial testing of the evidence, the judge essentially serves to review the prosecution's case. In the context that is perhaps best known for its adherence to rigorous truth-seeking processes_-scientific inquiry — it is never enough to merely review evidence; in science, investigators actively test theories and attempt to find evidence to disprove them. The inquisition's review process thus conflicts with the way we search for truth in a scientific context. As Chrisje Brants has put it:

From a scientific point of view, the presentation of two versions of events and the attempted falsification of the prosecution case that is characteristic of the adversarial system is surely a better way of arriving at the truth than the verification of the prosecutor's version by the judge- however many (limited) opportunities the defense may have had to influence the dossier pretrial and however nonpartisan the investigation. An inherent risk in procedures that rely on verification is not only that the police may be inclined to focus too much on one suspect once an apparently reasonable case can be made out against him or her-that is no different, perhaps even more likely in partydriven procedures-but that this will also lead to the police not looking for possible exculpatory facts, or, should they find such facts, attaching too little weight to them. This "mistake," or rather confirmation bias, will then be passed on to the other participants in the investigation: the prosecutor and, in the final event, the judge. ${ }^{122}$

Thus, even with the most objective and fair-minded inquisitor-including the most honorable magistrate leading the investigation envisioned by Risinger and

119. Findley \& Scott, supra note 21, at 307-23.

120. See Susan A. Bandes, Protecting the Innocent as the Primary Value of the Criminal Justice System, 7 Оніо St. J. Crim. L. 413, 424-25 (2009) (citing Jacqueline Hodgson, French Criminal Justice: A Comparative Account of the Investigation and Prosecution of Crime in France (2005)).

121. Brants, supra note 99 , at $172,174$.

122. Id. at 170. 


\section{ADVERSARIAL INQUISITIONS: RETHINKING THE SEARCH FOR THE TRUTH}

Risinger - that inquisitor will unavoidably be constrained by cognitive biases, public safety pressures, and a limited capacity to see the facts from the perspective of the (innocent) defendant. ${ }^{123}$ Only an advocate charged with responsibility for zealously pursuing the defendant's perspective, and only the defendant's perspective, can overcome those limitations and push for alternative understandings of the facts that might reveal the truth. Gerald Walpin has captured this distinction well:

The reality is that, whether that task of searching for and presenting facts is delegated to an inquisitorial judge or adversarial lawyers, the facts made available for consideration will depend on the ability, initiative, bias, determination, thoroughness, energy, aggressiveness, interest, knowledge, and motivation of the specific human being acting as inquisitorial judge or as adversarial lawyer in that specific case.

$\cdots$

... In the adversarial system, the lawyer for a party has the duty to act zealously and faithfully for his client. Zealous, faithful advocacy means the obligation to search out all favorable evidence, to seek, neutralize or destroy all unfavorable evidence, and to press the most favorable interpretation of the law for his client. That is simply not the obligation of an inquisitorial judge. ${ }^{124}$

The importance of that role, and the inability of judges to perform that role, is perhaps best reflected by the record of supposedly neutral and objective courts in evaluating convictions that DNA testing subsequently proved to be false. Brandon Garrett's analysis of the first 200 DNA exonerations found that reviewing courts, when affirming these wrongful convictions, frequently referenced their (incorrect) perceptions of the defendant's guilt. Addressing the evidence against these actually innocent appellants, fully half of the courts referred to the likely guilt of the defendant. ${ }^{125}$ Moreover, ten percent of the courts in such cases described the evidence of guilt against the actually innocent defendant as "overwhelming." ${ }^{26}$ And in nearly

123. More than thirty-five years ago, Mirjan Damaška recognized the manner in which cognitive biases inevitably compromise the neutrality of even the most well-intentioned neutral inquisitor. Damaška noted that, in order to question witnesses, the neutral magistrate must have some background information, drawn from the case dossier, about the case.

But [the magistrate's] necessary prior knowledge is, at the same time, a considerable shortcoming from the epistemological point of view. Being somewhat familiar with the case, the judge inevitably forms certain tentative hypotheses about the reality he is called upon to reconstruct. More or less imperceptibly, these preconceptions influence the kinds of questions he addresses to witnesses. More importantly, there is an everpresent danger that the judge will be more receptive to information conforming to his hypotheses than to that which clashes with them.

Damaška, supra note 5, at 1092.

124. Walpin, supra note 4, at 177 (first emphasis added) (footnote omitted).

125. Garrett, supra note 31, at 107-09.

126. $I d$. 
a third of the cases (thirty-two percent), courts found error but affirmed nonetheless because the error was deemed "harmless," a judgment that typically involves an assessment of likely guilt. ${ }^{127}$ Judges simply cannot be expected to recognize or zealously pursue facts supporting claims of innocence when they objectively view the likelihood of innocence to be so remote; only zealous advocates can be expected to push for such evidence and such a perspective.

\section{B. Shared Inquisitions}

Thus, the best procedure is one that attempts to harness the best aspects of both procedures, while minimizing the weaknesses of each. In a sense, this proposal is consistent with current trends toward blending the best features of the world's major criminal justice systems. Comparative scholars have observed that the world's major legal systems are in their broad features becoming less distinctive. ${ }^{128} \mathrm{My}$ proposal might be seen as a part of that development. I envision a system in which the adversaries share in shaping and directing the inquisitorial process.

The system I envision is one in which an accused person, whether claiming innocence or not, can choose whether to be prosecuted in the traditional adversarial system or under a system in which adversaries share in the inquisitorial search for the truth. The latter would be effectuated by assigning the case to a new truth-seeking agency, something that might be called an Office of Public Advocacy and that would house both prosecutors and defense attorneys who rotate between those roles and thereby become committed to the search for the truth with insights from both perspectives. The defense lawyer-who would remain adversarial and duty-bound to zealously advocate for her client when assigned to that role-would join with the prosecutor (also in an adversarial role) in jointly supervising the continuing investigation by police. This structure would be designed to create a culture that mutes the polarizing forces of career adversaries. Lawyers in this new Office of Public Advocacy would understand that the principle of law, or the forensic evidence they use in one case to obtain a conviction, might be the rule or evidence that will help convict their possibly innocent client in the next. It would ensure that these advocates see the human face of both the victim and the accused, and thereby help them appreciate the human toll taken by whatever they do, on either side of a case.

Such a sharing of inquisitorial powers is necessary to permit full exploration and testing of the evidence. Because the cognitive distortions that underlie tunnel vision are not deliberate or borne of ill will, they cannot be readily willed away. Research establishes that simply educating people about such biases and telling them to avoid them is ineffectual. ${ }^{129}$ Instead, what is needed is an institutional devil's advocatesomeone with an inherent interest in looking at the facts through a different lens. Research shows that counter-arguing can be effective in minimizing cognitive

127. $I d$.

128. See, e.g., David Luban et al., International and Transnational Criminal Law 136 (2010); Reamey, supra note 88, at 693.

129. Findley \& Scott, supra note 21, at 371. 


\section{ADVERSARIAL INQUISITIONS: RETHINKING THE SEARCH FOR THE TRUTH}

biases. ${ }^{130}$ And in this sense, the adversary system already offers the best possible model for providing institutional devil's advocates or counter-arguers. Defense counsel, charged with responsibility for single-mindedly pursuing the defendant's interests, plays that role. And because that role is so important in full exposition of the facts, the adversaries should share in the fact development process to ensure full inquiry and development of everything needed to truly understand the truth.

Such a practice of assigning the same attorneys alternately to prosecute and to defend is not unprecedented in the United States. While obviously not precisely the same model, in early nineteenth-century America public prosecutors worked parttime for low pay, so they had to maintain private practices on the side. ${ }^{131}$ Even today, there is precedent in some American jurisdictions for hiring or appointing private attorneys to prosecute some criminal cases ${ }^{132}$ there is no need to think of the prosecution function as inherently and exclusively the domain of executive officials who do nothing but prosecute cases.

In this new institution, the prosecutor and defense attorney would then be tasked to work together, as joint inquisitors-adversarial inquisitors, in a sense-to search for the truth and develop the evidence in the case. Thus, these joint, adversarial inquisitors would share equally in the responsibility for and access to the tools for developing the evidence in the case. Police and forensic analysts would answer to both and would be available to undertake investigations and analyses at the joint request of both. Police and lab analysts would become acculturated to answering to both sides, knowing that everything they do would be reviewed fully by both, and that they would be required to search as aggressively for evidence of innocence or alternative perpetrators as for evidence of the guilt of their primary suspect. Inequalities in resources and access to evidence would be muted, if not dissolved. In this way, even the pre-charging police investigation might be made more neutral and objective. Such an approach still might benefit from Risinger and Risinger's precharging investigating magistrate, but if that is unworkable, this approach at least offers another route to achieving improved pre-charging investigations.

This system also addresses another problem created by the special "innocent" plea envisioned by Bakken, Steel, and Risinger and Risinger. Bakken appropriately acknowledges that one potential problem with the "innocence procedure" he advocates "is that a formal plea of innocent might lead jurors to believe that defendants who plead not guilty are more likely to be guilty than those who plead innocent." ${ }^{133}$ His solution is to instruct jurors that the defendant has no obligation to plead innocent or to invoke the special innocence procedures. ${ }^{134} \mathrm{My}$ solution to this potential problem is a bit different: Don't change the plea by requiring the defendant to plead either the

130. Id. at $388-89$.

131. George Fisher, Plea Bargaining's Triumph: A History of Plea Bargaining in America 40-44 (2003).

132. Michael Edmund O'Neill, Private Vengeance and the Public Good, 12 U. PA. J. Const. L. 659, 660 (2010).

133. Bakken, supra note 3 , at 578 .

134. Id. 
traditional "not guilty" or the new plea of "innocent." Instead, just create two separate systems- the traditional American system and the adversarial inquisition proposed and described here- and let the defendant choose the one he wants to investigate and try him on his plea of "not guilty." 135 The jury need not even know which system is at play, and therefore would have no basis for second-guessing anyone's plea of "not guilty." Nor would the police necessarily know which side a lawyer is representing when she requests additional investigation. Biasing pressures would be minimized.

\section{Full Sharing of Evidence}

In return for these procedures, the defendant would have to waive the conflict of interest inherent in any such arrangement, but some defendants would no doubt do so to obtain the advantages of this alternative procedure. Defendants would also have to waive some privileges and confidentiality - they would have to agree that all evidence and witness statements would be developed jointly and shared between the parties. No longer would the parties hold their cards until trial or privately interview and prepare witnesses.

But the defendant would not be required to waive confidentiality of communications with counsel or the right to remain silent. In this regard, I part with Bakken, Steel, and Risinger and Risinger when they advocate requiring the defendant to waive nearly all constitutional rights to confidentiality and silence. ${ }^{136}$ As I have argued, waiver of such rights is not required by, nor even necessarily consistent with, a focus on searching for the truth. ${ }^{137}$

Nor are such waivers necessary as a practical matter; inquisitorial systems already function quite well without requiring full disclosure of defense information or waiver of confidentiality rights. In Switzerland, for example, the police and prosecution must disclose their entire files to the defense, but defense counsel is not reciprocally bound to disclose his or her file. ${ }^{138}$ Likewise, in Switzerland, while the prosecution must disclose its full file, defendants need not waive their right against self-incrimination; indeed, in Switzerland "[a] suspect never can be questioned as a witness." ${ }^{139}$ Similarly, in the Netherlands, the defendant may speak in his or her defense-although never under oath even at trial- "but only if he or she wishes to." ${ }^{140}$

Enabling adversaries to effectively advocate for their version of the truth means, at a minimum, that there must be full sharing of information between the parties. As Risinger and Risinger, along with Leon Friedman and others, have suggested,

135. Note that, while this system assumes a not guilty plea and a trial, it would also offer advantages to the vast majority of cases that are resolved ultimately by a guilty or no contest plea by helping to ensure that these pleas are fully informed and based on an accurate assessment of the evidence and the defendant's culpability.

136. Risinger \& Risinger, supra note 3, at 894-95.

137. See supra notes $78-87$ and accompanying text.

138. Killias, supra note 72 , at 141-42.

139. Id. at 143.

140. Brants, supra note 99, at 166. 


\section{ADVERSARIAL INQUISITIONS: RETHINKING THE SEARCH FOR THE TRUTH}

this must mean at least fuller discovery, ${ }^{141}$ and, as Lissa Griffin has suggested, stronger Brady requirements. ${ }^{142}$ But it must also mean more. As Dan Simon has put it, "the adjudicative process stands to benefit from enhancing the integrity of the evidence from which verdicts are made. This can be achieved foremost by making the investigatory process transparent to the factfinders." ${ }^{143}$ One of the critical problems with the current system's ability to assess truthfulness is the opacity of the investigative process itself. Juries and judges alike know and are told little about the processes that produced the apparently incriminating evidence. Fact finders typically know little about the subtleties of an eyewitness identification procedure, the pressures of an interrogation, or the improvements in a witness's certainty, coherence, and delivery that evolve over repeated interviews and coaching sessions-all of which can contribute to making weak evidence appear compelling. ${ }^{144}$ Making both parties a part of the shared investigative process pierces that opacity, while reducing biasing influences on the process.

Full disclosure of the prosecutor's file is not unworkable. It is the rule in many Continental systems. In Switzerland, for example, the right to be heard "imposes on all authorities (in all fields) the strict obligation to fully disclose the file prior to making any decision about a citizen." ${ }^{145}$ Similarly, in the Netherlands, the defense has the right to examine the prosecutor's complete dossier. ${ }^{146}$

As James Liebman has suggested, we also need to find ways to get police to internalize the search for innocence - and for non-matches. ${ }^{147}$ My proposal might do that. It would make police and prosecutors alike much more keenly aware that everything they do will be scrutinized by defense counsel, and will be subject to revision and reinvestigation by defense counsel-and not a defense counsel who is an "other," but a defense counsel who is a part of the truth-seeking team. As Zalman puts it in suggesting a much more modest right of defense counsel to seek judicial approval for a request for investigation, "defense requests for investigation would begin to make sense in a system of police and prosecutorial investigation that has

141. Leon Friedman, The Problem of Convicting Innocent Persons: How Often Does It Occur and How Can It Be Prevented?, 56 N.Y.L. Sch. L. Rev. 1053 (2011-12); Mosteller, supra note 5, at 329-35; see also Prosser, supra note 17; Risinger \& Risinger, supra note 3, at 886-90; Thomas, supra note 17, at 590-98. I, too, have previously advocated for fuller discovery as a partial antidote to tunnel vision. Findley \& Scott, supra note 21 , at 389-93.

142. Lissa Griffin, Pretrial Procedures for Innocent People: Reforming Brady, 56 N.Y.L. Sch. L. Rev. 969 (2011-12).

143. Simon, supra note 24 , at 147.

144. See id. at 182 .

145. Killias, supra note 72, at 140; id. at 141 ("[F]ull disclosure of the prosecution's file is the strict rule under all circumstances.").

146. Brants, supra note 99 , at 166.

147. James S. Liebman, Professor of Law, Columbia Law Sch., Panel Speaker at the New York Law School Symposium: Exonerating the Innocent: Pre-Trial Innocence Procedures (Nov. 5, 2010), http://nyls. mediasite.com/mediasite/Catalog/pages/catalog. aspx?catalog Id =001c2f34-622b-48e2-8d663e833b935fd8 (speaking in Panel II). 
shifted more toward developing something like a dossier, that developed internal review." ${ }^{148}$

Such an approach to investigation is neither unworkable nor unprecedented, as giving the defense some role in directing the police investigation has precedent in inquisitorial systems. ${ }^{149}$ Witnesses would be interviewed jointly to guard against coaching or manipulation by either side. This too is already the practice in some Continental systems. In Switzerland, for example, "[i]n practice, virtually all witnesses, experts, and other evidence are heard first by the police or the prosecutor (with the defendant and his or her counsel being present) during the pretrial investigation." ${ }^{50}$ Thus, in Switzerland "preparing' witnesses and experts before their hearing is strongly discouraged, and there are no 'witnesses for the prosecution' or 'for the defense,' but just individuals who contribute and assist the court in finding the truth." ${ }^{151}$ And all investigative reports, witness statements, laboratory reportsindeed, all evidence in the case-would be equally available to both sides (barring exceptional circumstances). Thus, the development and presentation of evidence would be undertaken much like it would in an inquisitorial system, except that the inquisition itself would benefit from the influence and ideas of individuals tasked with protecting their adversarial interests as well.

\section{Costs and Abuses}

One objection to this approach might be that it would be susceptible to abuse by over-zealous or even obstructionist defendants. Defenders would not likely abuse the investigation right, however, because: (1) the culture would be one of shared enterprise (lawyers would not want to alienate other lawyers, or law enforcement, upon whom they would rely); (2) results would be fully disclosable to the prosecution-defense teams would know that every wild-goose chase that produces nothing exculpatory would instead produce ammunition for the prosecution; and (3) abuses could be taken to a judge for protective orders.

Ideally, this would create a new culture of objectivity and neutrality in police investigations-and improved methods of both proving and disproving guilt. In an

148. Zalman, supra note 94 , at 86 .

149. "In France, as more generally in Continental law countries, the defendant ... has the right to request of the investigating magistrate that further investigations be carried out . . . and when confronted with experts' reports 'to ask for a counter-expertise or a complementary expertise' within ten days." Zalman, supra note 94, at 85 (footnote omitted) (citing Bron McKillop, Anatomy of a French Murder Case, 45 Ам. J. Сомp. L. 527, 538-40 (1997)) (internal quotation marks omitted). Similarly, in Switzerland, the defense does not undertake an independent investigation, but may ask at a pretrial hearing for an extension of the police investigation. Killias, supra note 72, at 141. Zalman notes, however, that a defense request for investigation or experts must be "filtered through the investigating magistrate." Zalman, supra note 94 , at 85 . My proposal does not automatically require such filtering, but would provide alternative checks on abuses, and the option for the prosecutor to invoke protection of the court when needed.

150. Killias, supra note 72, at 142 .

151. Id. 


\section{ADVERSARIAL INQUISITIONS: RETHINKING THE SEARCH FOR THE TRUTH}

adversarial process, natural human tendencies to seek confirming evidence, rather than disconfirming evidence, tend to lead to tunnel vision. ${ }^{152}$ Although looking for disconfirming evidence is often more probative-it is the method of scientific inquiry after all-confirmation biases make that mode of inquiry unnatural. ${ }^{153}$ Requiring police to serve both the prosecution and defense minimizes the tendency to serve only one objective-obtaining proof of guilt. Moreover, research confirms that, when people know their decisions are open for public scrutiny, they tend to make less biased decisions. ${ }^{154}$ Full disclosure, and service to both the prosecution and defense, therefore, should improve the ability or inclination of police to investigate objectively, both to find evidence of guilt and evidence of innocence. Indeed, Martin Killias argues that in inquisitorial systems like Switzerland's, the practice-encouraged by the ability of the defense to ask for additional police investigation-is that "the police often invest considerable resources to rule out the implication of any third party." ${ }^{155}$

For similar reasons, it is unlikely that the new approaches outlined here would entail substantial systemic costs in terms of false acquittals or erosion of public safety. Properly understood, the reforms envisioned here favor neither the defense nor the prosecution, but rather the system's access to the truth. In this sense, these reforms are intended to help move us beyond the traditional conception of trade-offs between "crime control" and "due process" 156 and toward a model of reliability. ${ }^{157}$

\section{CONCLUSION}

The American criminal justice system is not one designed well to find the truth. The record of failure, especially in the form of wrongful conviction of the innocent, confirms that it does not function as well as it should. This failure raises again the long-standing debate about whether an inquisitorial system might be better at finding the truth and protecting the innocent than the current American adversarial system. But in the end, both systems have strengths and weaknesses. The inquisitorial system's focus on truth-finding, and its commitment to objectivity and shared information, promises greater access to the truth. But the adversarial system's reliance on adversaries who are committed to seeking evidence and interpretations of the evidence that favor competing outcomes offers the best mechanism for ensuring that

152. Findley \& Scott, supra note 21 , at 309-11.

153. Id. at 312 .

154. "Psychological research has shown that when people feel publicly accountable for decisions, they exhibit less bias in their hypothesis testing strategies." Richard A. Leo, The Third Degree and the Origins of Psychological Interrogation in the United States, in Interrogations, Confessions, and Entrapment, supra note 83, at 99.

155. Killias, supra note 72, at 141.

156. For the seminal formulation of the competing "due process" and "crime control" models, see Herbert L. Packer, The Limits of the Criminal Sanction 150-73 (1968) and Herbert L. Packer, Two Models of the Criminal Process, 113 U. PA. L. Rev. 1 (1964).

157. For a fuller discussion of the way that a new "reliability" model is beginning to replace our understanding of competing "crime control" and "due process" models of criminal justice, see Findley, supra note 39. 
all possibilities are considered, thereby guarding against tunnel vision and confirmation biases. The search for the truth, therefore, should be enhanced by combining these strengths from both systems-the openness and commitment to neutrality in investigations from the inquisitorial system and the forced openmindedness that would be brought by permitting adversaries to jointly control that investigation. A change in culture and procedures is required to accomplish that melding, and that might be best served by creating the new Office of Public Advocacy, which I have outlined here. In the end, by eliminating the adversaries' ability to hide and manipulate evidence, and by eliminating the disparities that presently mark the system, this new model might indeed make the presentation and evaluation of the facts more truly adversarial, and hence more reliable at ascertaining the truth. 